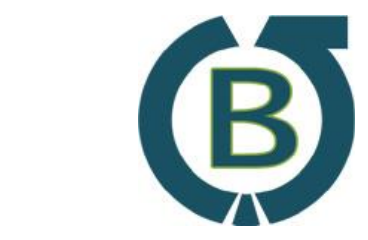

FACULTY OF MANAGEMENT \& FINANCE UNIVERSITY OF COLOMBO
Vol. 04, No. 01, June 2014
Colombo

Business Journal

International Journal

of Theory \& Practice

\title{
Opportunistic Behaviour and Psychological Contract between Employer and Employee
}

\author{
N. N. J. Navaratne ${ }^{a}$ \\ Department of Human Resources Management, University of Colombo, Sri Lanka
}

\begin{abstract}
It is assumed that employment agreement is not perfect or complete because, it never offers an account of virtues such as benevolence, effort, knowledge, or courage and it implies that the economic agent is "lawabiding" but not "fair". In a sense, what is legal does not equal to what is moral. Moreover, imperfect or incomplete agreement may create residual or remaining rights for both the employer (the contract maker) and employee (the contract maker) by nurturing an environment to get an opportunistic behaviour. But moral or ethical values such as justice from an employer and commitment from an employee changes individuals' utility or well-being function. Therefore, can assume that a decline from the opportunistic behaviour. In addition it may facilitate long-term psychological contract by creating a balance between how the employee is treated by the employer and what the employee puts into the job while minimizing opportunistic behaviour between them. Thus, all forms of justice and commitment are negatively related to opportunistic behaviour while positively influencing psychological contract. Using survey data collected from two hundred and seventy three, (273) fulltime employees at fourteen (14) manufacturing companies in the apparel industry in Sri Lanka, this study empirically tested the relationship between organizational justice from the employer perspective and commitment from the employee perspective as the originators of the psychological contract. The results of Correlation Test and Chi-Squared Test show a positive association among justice and commitment behaviour. Moreover, the findings of the research suggest that the utmost importance of moral or ethical values as an essential part of the business strategic decision-making behaviour.
\end{abstract}

Keywords: Employment Agreement, Imperfect, Opportunistic Behaviour, Psychological Contract

${ }^{a}$ Corresponding Author: nimal_n@fmf.cmb.ac.lk 


\section{Introduction}

Contemporary contract law support contractual exchange between two or more parties. As Vandenberghe (1999) noted, employment contract can be viewed as a combination of explicit and implicit agreements. But, employment contracts are usually incomplete therefore employer and employee may have residual rights (Hart, 1993) or remaining subjective decision making power on employee's effort (Leibenstein, 1984); and employees' knowledge in the professional organizations (Etzioni, 1964) and residual rights on employer's decision making. Residual rights can be defined as which are held by an employer or employee and have not been managed or controlled completely by employee or employer by using their legal power. Subsequently, parties who anticipate the opportunistic behaviour might refrain from investing in specific capital; this is known as the holdup problem (Vandenberghe, 1999).

Nagin et al. (2002) model of opportunism that they label as the "rational cheater" model of motivation posits that employees are self-interested actors who continuously probe their environment in search of ways to increase their welfare. Furthermore, it can be assumed that as a result of the residual rights each party will formulate his or her choices and preferences based behaviour on a subjective probability distribution over all possible types of his or her opponent. In order to achieve common goal of the organization both employee and employer need to share their effort and knowledge. To achieve that, the residual rights need to be controlled therefore organization can reduce an opportunistic behaviour and achieve its common goals. The idea of this paper is to discuss some mechanism to reduce the opportunistic behaviour and then enhance psychological contract between employer and employee.

The idea of the opportunism is a central concept in Williamson's $(1975,1993)$ Transaction Cost Economics (TCE) logic. However, TCE is finally concerned that hierarchical control mechanisms or sanctions are the only safeguards for opportunistic behaviour. But, the incomplete contracts simply avoid effectiveness of the hierarchical control mechanisms. Usually opportunity benefits encourage non-cooperate behaviour from both the employer and employee. For example, if the employer expects to pay minimum wages (the best is no payment) to the employee by using authority, it creates an incentive for non-cooperate behaviour. If the employee expects to use his/her minimum effort or knowledge to work (the best is no work), which also creates non-cooperative opportunistic behaviour. Let us assume that the employee does his/her minimum effort considering his/her self-interest maximization without considering the employer's choice behaviour. There is the possibility to the employer also decides to pay his/her minimum to the employee, considering his/her own self-interest without considering employee's choice behaviour. Either employee or employer acting individually and without benefit to the other would generate nothing in compensation.

In general, most of the organizations are based on a hierarchical structure with co-ordination at the centre. But, Lind et al. (1993) pointed out that "people generally recognize that ceding authority to another person provides an opportunity for exploitation, so they worry about obeying orders that might be guided by some covert, Machiavellian motive on the part of the authority"(p. 225). Watts and Zimmerman (1986), hold that managers take the opportunity to manage earnings in order to maximize their own utilities at the expense of the contracting parties and stakeholders. In that sense, it can be assumed that no consideration of the moral or ethical values creates the opportunistic behaviour and the rule of that behaviour gets the opportunities in an aggressive way. Thus, the lack of 
moral or ethical values indicates that someone seeks one's own well-being without considering other's well-being or someone can pursue his/her benefits through others' expenses.

Considering previous definitions of opportunistic behaviour this paper defines it as 'the tendency by one partner to cheat on the other'. If the employees feel that authority orders are trying to exploit them, then the work behaviour is affected. If the employer is willing to seek his/her better off from the employee's worst off, it violate the employee's rights. Therefore, psychological contract based on justice and commitment are needed in organization, to secure employer and employee's rights but not well discussed this emotional bond between employer and employee in the formal contractual agreement. The definition of the psychological contract by Sims (1994, p. 375) is "the set of expectations held by individual employee that specify what the individual and the organization expect to give to and receive from each other in the course of their working relationship") Armstrong (2012, p. 409) described that "psychological contracts are not developed by means of a single transaction; and they evolve over time and can be multi-faceted".

In this research, attempts have been made to address the opportunistic behaviour by examining employee agreement as an imperfect or incomplete one. Therefore, the objective of the research is to identify psychological contract is based on two ethical aspects such as justice and commitment in return it linked to reduce opportunistic behaviour of the employee and employer.

\section{Literature Review and Hypotheses Development}

Contractual arrangements are well recognized by Coase's thesis "The Nature of the Firm" (1937). Scholars indicate that contractual agreement is not enough for the proper employment relationship (Leibenstein, 1984; Hart, 1993). Employer can practice his/her authority to give employees directions, but it may cause alienation of the employees and further it is not able to override employee's autonomy. This is because employer's authority does not enable himself/herself to be put in a position to decide what employees are going to do. Therefore, employer's authority has restricted power to plan employee's individual pay-off. Therefore, it is better to assume that a contractual exchange without well-defined limits allow residue subjective power to the employer and to the employee. Based on the residual rights most of the employees who have competencies and skills may seek opportunistic behaviour (Hart, 1993) comparing to less experienced and less skilled employees in the business organizations. For this reason, the authority holds limited rights (at least partially) to direct these employees towards production activities by using its only legal power of control.

In this sense, residual rights situation of each party creates an independent subjective probability that is beyond the control or sanction power of the contractual agreement. If one party does good or wrong thing it will affect the other party and vice versa. Now the situation of employment relationship is based on the assurance or agreement between an employer and an employee. Since, "the person with assurance game preferences will behave cooperatively as long as he can be assured that the other person will behave like cooperatively" (Nida-Rumelin, 1997, p. 122). If one party chooses his/her actions ignoring other party's existence, and then the other party also does a same action. If one party tries to dominate or exploit other party, then other party also chooses non-cooperation as their dominant strategy.

Thus, important to understand that the incomplete contracts intensifying exploitation capability of the other party through following an opportunistic behaviour, if both not select cooperate strategy. As 
discussed by Etzioni (1964) and Leibenstein (1984), contract is not complete on knowledge specificity and the employee's effort side that creates residual subjective power to the employee. These residual rights are allowed to have a free choice power to the both party. In fact, ethic based behaviour such as organizational justice and commitment is needed to gain the respect and manage the long-term interests of the both parties by reducing opportunistic behaviour. However, if employee or employer was not motivated on his/her own interest's maximization, there is no reason to discuss interest conflict and then need of the organizational justice and commitment would not arise. Basically, two factors may encourage the employees to estimate that opportunistic behaviour is a better strategy than a cooperate behaviour.

First, the motivation to secure their short-term better off from the expenses at an employer creates an opportunistic behaviour among the employees. Opportunistic behaviour always encourages choosing the non-cooperative behaviour is a better choice than cooperative behaviour at any point in time. For example, if an employee becomes aware of his/her subjective ability on knowledge and effort side that may offer a higher probability to seek his or her own better off from the worst off an employer.

Second, most of the employees are willing to seek an opportunistic behaviour from the belief that his/her personal influences are more significant or less insignificant to the organization. On the other hand, if an employee perceives that his/her efforts are gained cost than benefits then he/she becomes motivated to contribute less effort to the organization. These two situations are known as the 'freerider' problem in neo-classical economics.

The opportunistic behaviour can work as the dominant driving force to employer on two factors. These factors may lead to employer to estimate that the non-cooperation is a better strategy than the cooperation at any point in time by using authority power and residual rights on incompleteness of the contracts.

First, authority power encourages employer to seek non-cooperate behaviour. Because the employer has authority power to issues the orders and control power over an employee. The employer can practice his/her power as an opportunity for exploitation the employee considering the "machine model" developed by Frederick Taylor. But, if the employer appears to be acting unfairly, the employees question the employer's motives and may well disobey (Lind et al., 1993, p. 225).

Second, incomplete contracts allow residual rights to employer, including reneging (Milgrom \& Roberts, 1992) and incongruence (Morrison \& Robinson, 1997). The former occurs as a result of the unwillingness to fulfil employer's obligations to employee. For example, pay reduction, new requirements for promotions, extension of probation period etc. The latter occurs when the two parties to the exchange have different understandings of the promises made. For example, assurance of the life time employment but consequently applies lay off procedures.

If, both parties were judged their actions on fulfilment of long-term interests that generate better relationship between employee and employer but this relationship needs moral or ethical egoism based on justice and commitment. As a result of ethical behaviour long-term psychological contract may originate and that behaviour may gain better outcomes for the both party than the individual rational behaviour as has been noted before. 
Normally, long-term employment contracts are incomplete (Vandenberghe, 1999). A contract is incomplete when it does not specify each party's obligations in every conceivable eventuality (Hart, 1987). Consequently, the person who is concerned about long run well-being in organization or the society usually needs to be concerned about psychological contract rather than rational maximization or first order choice behaviour because the situation is interdependent. The employment contract might be incomplete if parties are not able to foresee all future contingencies. Thus, impulse control model like justice from organization and commitment from employee will substitute opportunistic behavioural aspects but facilitates to get mutually understood situation than rational maximization behaviour. Also, justice and commitment become an agreement or assurance between the partners.

Thus, Lind \& Tyler (1988) proposed that the group-value theory of justice for the better relationship between individuals and their organizations. They considered that the justice is the key to develop cooperate based relationship and successful commitment behaviour from the employee in the organizations. Consequently, employee's perception of the organizational justice breeds trust (Armstrong, 2009) that enhances the employees' long-term commitment behaviour by changing of the attitudes, beliefs, and perceptions by developing informal short-term and long-term give and take obligations between employee and employer and that caused to enhance psychological contract between them.

The moral or ethical egoist considers the interests of others according to his/her own justification because it is in his/her long-term advantage to do so. The long-term advantage for either moral or ethical egoists can be achieved through cooperative game rather than the self-interested behaviour, but this cooperate behaviour between employer and employee should base on the organizational justice. A cooperative game is one in which the players have common interests and are allowed to get together and act jointly (McDonald, 1977,p. 102).

The justice based on ethical egoist behaviour is not only described self-interested motivation, but also described that behaviour on consequences. The consideration of both self-interest and consequences are the important points to the attain goals or end-results. The consequences explained rightness or wrongness of the action depend upon the action's effects. In that case, the act behaviour, which direct to the goals or end-results, becomes rational.

Therefore, the employer must concern employee's interests to achieve the goals and employee must concerned an employer's interests for achieve his/her own-interests. In this manner, justice becomes the rule for stability of the choice behaviour based on psychological contract. When employer and employee take moral or ethical consideration into order his/her preferences it is paved the way for proper employment relationship between them.

In long run, justifications on knowledge subsequently provide the permanent agreement on trust to each other. The trust produces the only way to determine the employee's present interests and future expectations from their own volition are by giving them reason to do certain behaviour. Therefore, better to understand trust as an accumulative value of justice at a given time and commitment is the resulted certain behaviour from the wedge of the past knowledge and the future expectations. 
In this sense, the justice and commitment create the ability of employee to assume as him or herself as part of the organization with shared goals. Therefore employee is willing to internalize the organizational goals and values continuously to become a corporate member, because it is the specific way to achieve employee's self-interests.

Employee, who internalizes the organizational goals and values, will not leave the organization during bad periods. They cannot be attracted by better benefits from the other organization. On one hand, those who tempt to seek personal well-being by defect they may get negative consequences. On the other hand, moral or ethical values such as justice and commitment are lowering the temptation to follow opportunistic behaviour. As Axelrod explained (1997) when a person strongly internalizes a justice, there is negative temptation to defect rather than positive. This internalization will cause to cooperative behaviour by restricting the opportunistic act by defect because "the violating an established norm is psychologically painful even if the direct material benefits are positive" (Axelrod, 1997, p. 57).

\subsection{Organizational Justice and Employee's Commitment}

The justice provides motivations to respect other's rights to exist by choosing what is morally right, considering that is the way to achieve self-interests. Further, sound fairness principles can provide clear standards by which a peer's behaviour can be evaluated. Usually, sound fairness principles facilitate to detect free riders easily (Folger \& Cropanzano, 1998).

The relationship between employer and employee based on justice may originate commitment behaviour in considering the long-term mutual well-being. If there are no any other environmental restrictions, better to assume that commitment behaviour is harder to generate without justice. The commitment behaviour is between the wedge of the past knowledge and the trust on future expectations, hence better to assume that commitment behaviour is always related to present. Salancik (1977) defined commitment as "a state of being in which an individual becomes bound by his actions and through these actions to beliefs that sustain the activities and his own involvement" (p. 62).

Therefore "a commitment is motivationally credible if the players continue to want to honour the commitment at the time of performance (North, 1993, p. 13)." If the action is not committed, the intention of act considers different thoughts, different pathways of action, different kind of such act and different means before act does. But, the committed action is focused on single action on selfenforcing motives, but it should be rooted with a specific organizational situation like justice.

Sen (1982) defined commitment, as "a person choosing an act that he believes will yield a lower level of personal welfare to him than an alternative that is available to him" (p. 92). Organizational commitments have multi-dimension but mainly on three, that the employee's feel he/she want to remain the organization (Affective Commitment) or he/she need to remain the organization (Continuance Commitment) and/or he/she ought to remain the organization (Normative Commitment). Meyer \& Allen (1997), define affective commitment as the "employee's emotional attachment to, identification with, and involvement in the organisation" p. (11). The employee with a strong affective commitment will not leave the organization because they want to do so (Meyer \& Allen, 1991). Meyer \& Allen (1997) defined continuance commitment as "to the employee's awareness that costs are associated with leaving the organization". Meyer \& Allen (1997) defined normative commitment as "an employee's feelings of obligation to remain with the organization" (p. 60). 
Justice studies found that judgments about procedural justice may be more strongly related to evaluation of supervision and organizational commitment, while distributive justice is more strongly linked with job satisfaction and intent to stay (Folger \& Konovsky, 1989; McFarlin \& Sweeney, 1992). According to Robbins et al., (2000) organizational commitment and distributive justice judgments are reciprocally related. Kim \& Maubornge (1998) argue that "when people feel their strategic decisionmaking processes are fair, they display a high level voluntary cooperation based on their attitude of trust and commitment" (p. 324). Therefore we better to assume that commitment to operate a fair process would produce more fair outcomes than outcomes from the unfair process to the business organizations.

\subsection{Justice and Employment Relationship}

If, employee faced with the psychosocial (inter-personal) interest conflicts within an organizational structure that will influence to proper job behaviour. Thus, Etzioni (1993, p. 27) pointed out that the control pyramid could be served as a conflict resolve function. If 'conflict of interests' being suppressed by authority power, it can result in stagnation and failure to adapt to changed circumstances and/or erode the bond of group solidarity because of an accumulation of hostility. Therefore management is conventionally responsible for reduce conflict through coordination.

However, all activities cannot be coordinated and organized under management authority alone. This is because; authority structure may not be able to completely predict employees' mental state and behavioural patterns, thus rationality is 'bounded'. But it is important to note that this bounded rationality does not arise because of inability to predict employees' mental and behavioural patterns, but also authority or employer may treats the employees as parts of given environment, and doesn't try to predict the behaviour and mental state. Therefore, whatever method exists to control, it is important to consider the justice that can settle down to cooperative behaviour as a resolving mechanism for the opportunistic behaviour. In order to reduce a possible opportunistic behaviour between the employer and the employee, internalization of the justice is the only valid moral or ethical consideration from the employer.

A conceptual element of justice is fairness (Rawls, 1985). Justice will provide converse association between moral aspects of both parties (Rawls, 1999; Buchannan \& Mathieu, 1986). If, an employee and an employer have a reason to think that the choice behaviour of each party is improbable on the basis of self-interest, then both will be willing to behave according to minimum moral obligation such as justice. The notion of justice or fairness is widely recognized as essential for mutually satisfying exchanges and is tied to two concepts: procedural justice and distributive justice (Lind \& Tyler, 1988; Tyler \& Lind, 1992).

The procedural justice refers to fairness issues concerning the methods, mechanisms, and processes used to determine outcomes. The distributive justice is the perceived fairness of the outcomes or allocations that an individual receives (Folger \& Cropanzano, 1998).

The justice specifies what actions one should take in a given environment to overcome the problems related to choices of self-maximization. Now, employer and employee consider choice behaviour from the preferences based on psychological contract. According to Rousseau and Wade- 
Benzoni (1994), psychological contract acts to sustain the employment relationship over time. That is given better long-term results than individuals working alone as a separate entity. Therefore, achievement of common goal always associated with shared values posturing by justice. Moreover, Guzzo\& Noonan (1994, p. 452) stress that the fulfilment of the psychological contract in both transactional and relational terms influences employee loyalty and commitment. Barrett-Howard and Tyler (1986) found that procedural justice are central to individuals and have strong social psychological consequences.

When employee chooses their preferences constraint according to organizational justice, it becomes the independent variable and organizational commitment becomes the dependent variable. Justice is a cause of commitment behaviour. Commitment is an effect of justice. Justice creates cooperation between employer and employee that then become to employee's commitment binding or releasing device. Since this study sought to obtain an individual's justice perceptions from employer and employee by using a single key informant was considered to be appropriate. Based on above discussion following hypotheses can be stated.

Hypothesis 1: Procedural justice (PJ) is positively related with distributive justice (DJ)

Hypothesis 2: Procedural justice (PJ) is positively related with affective (AC), continuous (CC) and normative (NC) commitment.

Hypothesis 3: Distributive justice (DJ) is positively related with affective (AC), continuous (CC) and normative (NC) commitment.

Hypothesis 4: Affective (AC), continuous (CC) and normative commitment (NC) reduce an opportunistic behaviour.

\subsection{Conceptual Model}

A model (Figure 1) is tested that derived from a review of the literature by integrating theory and research relating to the organizational justice, commitment and their relationship to opportunistic behaviour by creating psychological contract between employer and employee.

Figure 1: Relationship between Dependent and Independent Variables

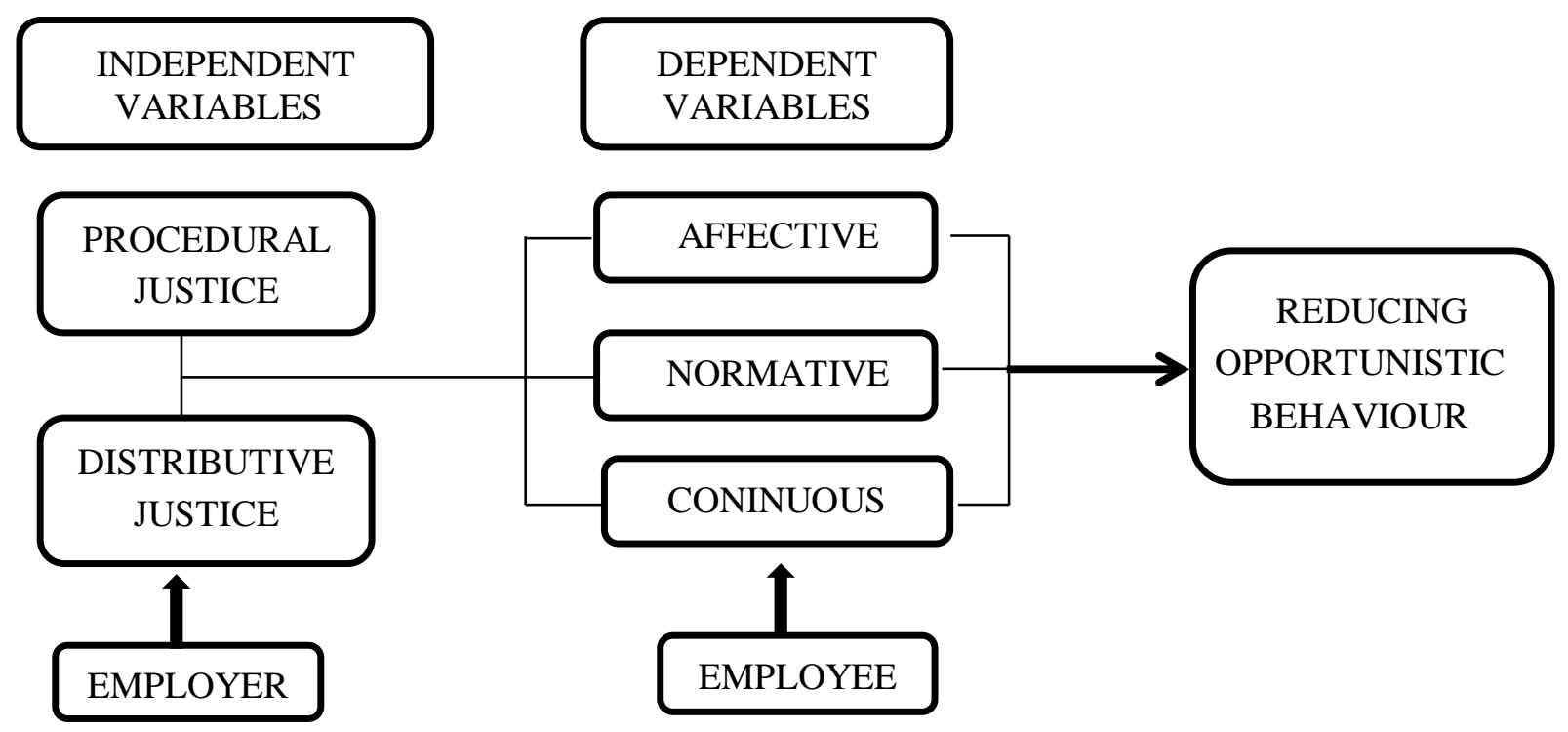

\section{Research Methods}


The data for this study was obtained from the two factories are wholly owned foreign companies, five factories are joint ventures, and six factories are wholly owned local investors but in non-difficult area and one factory from difficult rural area. Five out of the fourteen factories are situated in two Export Processing Zones (EPZs) in Sri Lanka.

Before the questionnaire was distributed among the employees, the general manager or some other top managers at each selected companies were be contacted, explained about this study, and asked for a commitment to participate. Some top managers allowed distributing the questionnaire directly to the employees, some were asked through the work leaders and some were asked to the middle managers to distribute. But, some top managers refused to participation to this study and some managers did not distribute the questionnaire among the employees as they were agreed. However two hundred seventy three fulltime employees (500 employees considered as the sample frame) from fourteen companies were returned their questionnaires.

\subsection{The Research Instrument}

A structured questionnaire was used for data collection, using self-report responses. This approach was consistent with assessing respondent's attitudes towards the organizational justice and employees' commitment. Furthermore, self-report offers a valid approach for the measurement of individual attitudes. The organizational commitment questionnaire consists of eleven scales. Seven scales out of eleven were originally designed by Cook and Wall's (1980) to measure employees' affective commitment to their employing organization. Bar-Hayim \& Berman (1992) also used these items to their researches. Other four questions used by Meyer and Allen (1997) to measure organizational continuous and normative commitments were used by this research to measure respondents', continuance and normative commitment. Procedural justice was measured in this study with the scales constructed by the author by referring previous organizational justice researches by developing the eleven scales because there were too few studies available to get the questions on procedural justice. Two scale items used to measure distributive justice from the research such as Folger \& Konovsky (1989), Fields et al. (2000).Using 5-point scale, the response categories for each item ranged from strongly agree to strongly disagree.

Managers and the employees used the same two-page questionnaire for completion with Likert 5 scales. In addition to the questionnaire, the 14 managers including the human resource managers (6 participants) and the factory managers (8 participants) were interviewed ranged from 20 to 40 minutes in length. During the interviews, participants were asked to describe what kind of well-fare facilities are providing to the employees and their perspectives regarding the employees.

\subsection{Sample of the Study}

Data for this study was obtained from two hundred seventy three (273) fulltime employees from fourteen (14) Garment Factories in Sri Lanka. A questionnaire was distributed to these workers, which guaranteed complete confidentiality. Some questionnaire was distributed through work committees, some through the work leaders, the managers and personally by the researcher. Workforce capacity in selected factories represented a broad range from maximum 4,500 to minimum 215 full-time employees. All 14 Garment Factories are 100 percent privately owned and manufacture mainly to export market. 
Within each factory, simple random sampling procedures were used to ensure an adequate representation of workers from all major occupational groups that agreed to participate in the study. Most of the participants were female employees (70\%) and between the age of 18-32 years. The respondents can be classified into four homogeneous occupational groups. They were: (1) professional, (2) managerial, (3) clerical, (4) blue-collar workers. Questionnaires were returned from two hundred three four of the five hundred in the sample frame, a response rate of 54.8 percent.

\section{Data Analysis and Discussion}

The primary analytical techniques used to test the hypotheses in this study were correlation analysis and the Pearson's Chi-Squared Test for the all companies (Table 1). Table 2 represents tested $\mathrm{P}$ values that are statistically significant for the all variables of the research. One of the most significant characteristics among 14 companies is significant relationship between organizational justice perceptions and affective commitment that may reduce an opportunistic choice behaviour between employer and employee by developing long term psychological contract among them.

Table 1: Correlation Matrix

\begin{tabular}{|c|c|c|c|c|c|c|}
\hline & $\mathrm{PJ}$ & & DJ & $\mathrm{AC}$ & $\mathrm{CC}$ & \\
\hline & $-\quad-$ & - & - & & & \\
\hline DJ & $0.901 * * *$ & - & - & - & & \\
\hline $\mathrm{AC}$ & $0.838 * * *$ & & $0.786^{* *}$ & - & - & \\
\hline $\mathrm{CC}$ & $0.869 * * *$ & & $0.865 * *$ & & $0.893 * * *$ & \\
\hline $\mathrm{NC}$ & $0.627 * * 0$ & $33 * * *$ & & 0.312 & $0.518^{*}$ & - \\
\hline \multicolumn{7}{|c|}{ Significant at $* * * \mathrm{P}<0.01 * * \mathrm{P}<0.05 * \mathrm{P}<0.10$} \\
\hline
\end{tabular}

\subsection{Pearson's chi-squared test}

Author is used the statistical package $\mathrm{R}$ for the analysis of these shrunken tables. Table 2 presents the Chi-Squared dependency or independency relationships between the variables and $\mathrm{P}$ value.

Table 2: Results of the Chi-Squired Test

\begin{tabular}{llllll}
\hline \multicolumn{2}{c}{ PJ } & DJ & AC & CC & NC \\
\hline PJ & $*$ & $*$ & $*$ & $*$ & $*$ \\
DJ & $.000(D)$ & $*$ & $*$ & $*$ & $*$ \\
AC & $.000(D)$ & $.0004(D)$ & $*$ & $*$ & $*$ \\
CC & $.000(D)$ & $.0001(D)$ & $.000(D)$ & $*$ & $*$ \\
NC & $.000(D)$ & $.0002(D)$ & $.000(D)$ & $.000(D)$ & $*$ \\
PO & $.000(D)$ & $.000(D)$ & $.000(D)$ & $.000(D)$ & $.000(D)$ \\
& & & & \\
D=Dependent & ID=Independent
\end{tabular}

Hypothesis 1 predicted that positive relationship between procedural justice and distributive justice and, the research also found a very significant relationship between procedural justice and distributive justice. Thus procedural justice of business decision making process enhances the distributive justice. 
Hypothesis 2 predicted that Procedural justice (PJ) is positively related with affective (AC), continuous (CC), and normative (NC) commitment. As shown in Table 1 procedural justice is associated with the all commitment behaviour of the employees and mostly associated with affective commitment. Folger \& Konovsky (1989) McFarlin \& Sweeney (1992) Lind \& Tyler (1988) also reported that procedural justice has close association with the organizational commitment but of this research found that continuous commitment has high significant relationship with procedural justice.

Hypothesis 3 predicted that Distributive justice (DJ) is positively related with affective (AC), continuous (CC) and normative (NC) commitment. As displays in Table 1, distributive justice is significantly associated with the continuous commitment than other two commitments. Leventhal (1976), Folger \& Konovsky (1989), and McFarlin \& Sweeney (1992) observed that distributive justice associated with the organizational commitment.

Hypothesis 4 predicted that Affective (AC), continuous (CC) and normative commitment (NC) reduce an opportunistic behaviour. When employer select his or her behaviour based on organizational justice and employee behaviour on organizational commitment that can be observed less opportunistic behaviour choices among them. According to Meyer, Stanely, Hercovitch \& Topolnytsky (2002), all the three forms of organizational commitment correlate negatively with withdrawal organization, turnover intention, and turnover and correlate positively with work behaviour such as attendance, job performance, and organization citizenship behaviour (OCB). In this sense the research results suggest that organizational justice and commitment might have power to reduce employer and employee opportunistic behavioural choices and that work behaviour might have benefits for employees and employers.

The research has found a very significant positive relationship of procedural justice and distributive justice with the continuous commitment. Several authors have found that a positive relation between organizational justice and commitment (Folger \& Konovsky, 1989; McFarlin \& Sweeney, 1992; Lind \& Tyler, 1988) and many researchers have found a very significant positive relationship between procedural justice and affective commitment.

\section{Conclusions, Limitations and Directions for Future Research}

An improvement of the opportunistic behaviour due to the imperfect of incomplete employment agreement between employer and employee brings disadvantages to the both parties and finally to the organization. If they willing to consider moral or ethical choices such as justice and commitment in to their choice making behaviour (decision-making), that would facilitate mutual better off situations rather than individual maximization or self-welfare goal choice making behaviour by reducing an opportunistic choices.

As a result of moral or ethical choices based on justice and commitment may change utility functions of an employer as well as an employee, thus action behaviour of the both parties could be influenced. The justice based choice behaviour will affect to change the actions, considering own long-term advantages in practical life. Therefore employee's perception of the organizational justice intends to contribute to common feelings with exposure to share organizational values and goals considering long-term consequences of the actions. This is commitment behaviour but it promotes from other than rule-based conduct or pre-commitment behaviour in a society. 
Therefore, the paper presents an affective relationship between employer and employee cannot overlook the important authenticity played by moral or ethical values such as justice and commitment to make psychological contract between them. Because, justice and commitment are providing an understanding of cooperation and success to the own long-term advantages as well as this long-term choice behaviour becomes to respect the wishes and requirements of the total society.

The first limitation of the study was the selection of the participants and the factories. This survey occurred primarily during the two months period. Considering the total employment $(276,821$ employees) in apparel industry, this sample size was small (273 employees) and less than one per cent. Considering the total existing apparels factories (about 891 factories), the sample figure (14 factories) is less than two per cent.

A second limitation of this study relates to confidentiality for participants. Some questionnaires distributed to the employees through the management. Every factory in this trade has high security procedures; therefore most middle managers were asked the permission from the top management. Some top managers allowed distributing the questionnaire directly to the employees or through the workers committees but some mangers appointed a middle manager as a coordinator.

Every employee was asked to enclose the questionnaire an envelope and closed it before return. However, the author afraid some answers may not revealed the real situation from the answers of the respondents. But most of the employees are openly criticized their supervisors and managers without considering how the questionnaire was delivered. Third, the limitations of the items are in the questionnaire. For example, for realized the distributive justice used only two items and for the normative commitment used only one item.

Third limitation is the possible effect of common method bias/variance as all variables were measured from only one source.

\section{Implication for Organizations}

This study has several implications for the business organizations. First, decision-makers in organization should be aware that employment agreement is not complete or perfect therefore if they put their own economic well-being above all else they should not expect employee's commitment to the organizations. Second, if they want to keep employee's organizational commitment high they must commit to give a priority in their commitment to organizational justice. Third, if the both parties would like to reduce opportunistic behaviour in considering justice and commitment it may help to achieve long-term ethical based egoistic well-being to the employer and employee.

\section{References}

Armstrong, M. (2012).Armstrong's hand book of human resource management practice (12 $\left.{ }^{\text {th }} \mathrm{Ed}\right)$. Kogan Page.

Bar-Hayim, A., \& Berman, G.S. (1992).The dimensions of Organizational Commitment.Journal of Organizational Behaviour, 13(4), 379-387.

Coase, R.H. (1937). The Nature of the Firm, in Williamson, O.E., \& Sidney G. Winter (Eds.), The Nature of the Firm: Origins, Evolution, and Development (1991), New York: Oxford University Press.

Cook, J.D., \& Wall, T.D. (1980). New Work Attitude measures of Trust, Organizational 
Commitment and Personal Need Nonfulfillment. Journal of Occupational Psychology, 53, 39-52. Etzioni, A. (1988). The Model Dimension: Toward a New Economics. New York: Free press. Fields, D., Pang, M., \& Chiu C. (2000).Distributive and Procedural Justice as Predictors of Employees Outcomes in Hong Kong. Journal of Organizational Behaviour, 21, 547-562. Folger, R., \& Cropanzano, R. (1998). Organizational Justice and Human Resource Management, USA: SAGE Publications.

Folger, R. \& Konovsky, M. A. (1989), "Effects of Procedural and Distributive Justice on Reactions to Pay Raise Decisions". Academy of Management Journal, 32,115-130.

Guzzo, R.A, \& Noonan, K.A (1994).Human resource practices as communications and the psychological contract. Human Resource Management, 33(3), 447-462.

Hart, O.D. (1987). Incomplete contracts. In: Eatwell, Milgate, Newman (Eds.), The New Palgrave: A Dictionary of Economics. Macmillan, London.

Hart, O. D. (1993). Incomplete Contracts and the Theory of the Firm In The Nature of the Firm; Origins, Evolution, and Development, Oliver E. Williamson and Sidney G. Winter (Edits.) 1993, New York: Oxford University Press.

Barrett-Howard, E, \& Tyler T.E. (1986).Procedural justice as a criterion in allocation decisions. Journal of Personality and Social Psychology, 50, 296-304.

Kahneman, D., Knetsch, J.L.,\& Thaler, R.H. (1986).Fairness and the Assumptions of Economics.Journal of Business, 59(4), 285-300.

Kim, W. C., \&Mauborgne (1998).Procedural justice, strategic decision making, and the Knowledge management. Strategic Management Journal, 19, 323-338.

Koehn, D. (1996). The Ethics of Business: Moving Beyond Legalism. Ethics \& Behaviour, 6(1), 1-16.

Leibenstein, H. (1984). The Japanese Management System: An X-Efficiency Game Theory Analysis In The Economic Analysis of the Japanese Firm. Masahiko Aoki (Ed): 331-357.

Leventhal, G.S. (1980). What Should Be Done with Equity Theory? New Approaches to the Study of Fairness in Social Relationships in Kenneth J. Gergen and Martins S. Greenberg and Richard. Willis, H. (Eds.) Social Exchange: Advances in Theory and Research. New York: Plenum Press.

Lind, A. E., \& Tyler, T. R. (1988).The Social Psychology of Procedural Justice, New York: Plenum Press.

Lind, A. E., Kulik, C.T., Ambrose, M., \& Park, M. de V. V. (1993). Individual and Corporate Dispute Resolution: Using Procedural Fairness as a Decision Heuristic. Administrative Science Quarterly, 38, 224-251.

McDonald, J. (1977). The Game of Business. New York: Anchor Book.

McFarlin, D.B., \& Sweeney, P. D. (1992).Distributive and Procedural Justice as Predictors of Satisfaction with Personal and Organizational Outcomes. Academy of Management Journal, 35, 626-637.

Meyer, J.P., Stanley, D.J., Herscovitch, L., \& Topolnytsky, L. (2002). Affective, continuance and normative commitment to the organization: A meta-analysis of antecedents, correlates and consequences. Journal of Vocational Behaviour, 61, 20-52.

Meyer, J. P., \& Allen, N. J. (1997).Commitment in the Workplace: Theory, Research and Application, London: SAGE Publications.

Meyer, J.P. \& Allen, N.J. (1991). A Three-Component Conceptualization of Organizational Commitment. Human Resource Management Review, 1, 61-89.

Milgrom, P., \& Roberts, J. (1992).Economics, Organization and Management. New Jersey: Prentice 
Hall International Inc.

Morrison, E.W., \& Robinson, S.L. (1997).When employees feel betrayed: a model of how psychological contract violation develops. Academy of Management Review, 22, 226-256.

Nagin, D.S, Rebitzer, J.B., Sanders, S., \&Taylor, L.J. (2002). Monitoring, Motivation, and Management: The Determinants of Opportunistic Behaviour in a Field Experiment. American Economic Review, 92(4), 850-873.

Nida-Rumelin, J. (1997). Economic Rationality and Practical Reason. The Netherlands: Kluwer Academic Publisher.

North, D. (1993). Institutions and Credible Commitment. Journal of Institutional and Theoretical Economics, 149, 11-23.

Rawls, J. (1985). Justice as Fairness: Political not Metaphysical. Philosophy \& Public Affairs, 14, 223-251.

Robbins, T.L. Summers, T.P, \& Miller, J.L. (2000).Intra- and Inter-Justice Relationships: Assessing The Direction. Human Relations, 53, 1329-1355.

Rousseau, D. M., \& Wade-Benzoni, K. (1994). Linking strategy and human resource practices: how employee and customer contracts are created. Human Resource Management, 33(3), 463-489.

Salancik, G.R. (1977). Commitment and the Control of Organizational Behaviour and Belief in B.M.Staw and G.R. Salancik (Eds.), New Directions in Organizational Behaviour.1-54.

Sen, A. K. (1982), Choice, Welfare and Measurement. Oxford: Blackwell.

Sims, R. R. (1994). Human resource management's role in clarifying the new psychological contract. Human Resource Management, 33(3), 373-382.

Straus, M.A. (1979). Measuring Intrafamily Conflict and Violence: The Conflict Tactics (CT)

Scales.Journal of Marriage and the Family, February, 75-88.

Tyler, T.R., \& Lind, E.A. (1992).A relational Model of Authority in Groups in M.P. Zanna (Eds.), Advances in Experimental Social Psychology, 25, 115-119.

Vandenberghe, A.S. (1999). Labor Contracts, Netherlands School for Social and Economic Policy Research Utrecht University, 541-560.

Watts, R.L., \& Zimmerman, J.L. (1986). Positive Accounting Theory: A Ten Year Perspective. The Accounting Review, 65(1), 131-156.

Williamson, O.E. (1975). Markets and Hierarchies: Analysis and antitrust Implications. New York: Free Press. 